\title{
A Case Study of Desertification in Haiti
}

\author{
Dr. Vereda Johnson Williams \\ Associate Professor \\ Economics and Finance Department, School of Business and Economics \\ North Carolina A\&T State University, Greensboro, NC 27411, USA \\ E-mail: vkncat@aol.com
}

Received: February 27, 2011

Accepted: March 24, 2011

doi:10.5539/jsd.v4n3p20

\begin{abstract}
One of the largest Caribbean nations, Haiti has 27,720 Square kilometers of land. Less that $20 \%$ of the land under cultivation is appropriate for agriculture. Once covered by forest, this country has been heavily logged and now mostly deforested. The majority of the arable land is being farmed beyond their carrying capacity. The total area under agriculture production is 6 times greater than the estimated areas suitable for agriculture resulting in significant deterioration of the land. Although the national governments as well as other governments have made several attempts to combat desertification, few initiatives have been successful. This research will: (1) review desertification, (2) assess the current state of desertification in Haiti and on the island of Hispaniola, (3) review the impact of internal and external programs designed to reverse the effects of desertification, (4) compare the indicators of desertification that exist on the island of Hispaniola, and (5) discuss the consequences of desertification for Haiti as well as proactive strategies for reversing the negative effects.
\end{abstract}

Keywords: Desertification, Environment, Ecology, Deforestation, Degradation of land

\section{Introduction}

Haiti is the poorest country in the Western Hemisphere with eighty percent of the population living under the poverty line. Sixty six percent of all Haitians depend on the agricultural sector, small-scale subsistence farming, and remain vulnerable to damage from frequent natural disasters exacerbated by the country's widespread deforestation. Desertification threatens the livelihoods of some of the poorest and most vulnerable populations on the planet including Haiti.

Haiti's environment is one of the most devastated in the world. Only thirty percent of the land is suitable for cultivation, with the result that the majority of the rural poor have a desperate struggle for survival on marginal areas. Haiti has dropped from sixty percent forest cover to less than 1 percent. Haiti has become an environmental disaster and a human catastrophe. The recent hurricane has only magnified an already hopeless situation. Because the political situation in Haiti is so desperate as well, it has become necessary to bring in support from outside of the country. With the forest cover gone, floods ravage the country at each rainfall and the topsoil washes into the sea. Although several environmental problems persist in Haiti including soil erosion, deforestation, and desertification, this research will concentrate on the problem of desertification. More specifically, this research is an analysis of one of the major environmental hazards affecting the Haiti, desertification.

The objective of this research is to review the literature as it pertains to desertification, to define the current status of desertification in Haiti, to document the internal and external programs that were designed to reverse the negative effects of desertification in Haiti, and to analyze Haitian indicators of desertification as well as their consequences.

\section{A Review of Desertification}

Desertification is caused primarily by human activities and climatic variations. It occurs because dryland ecosystems are extremely vulnerable to over exploitation and inappropriate land use, which can all undermine land degradation and productivity. Desertification is a result of a long-term failure to balance demand for and supply of ecosystem services in dry lands. The pressure is increasing on dry land ecosystems for providing services such as food, forage, fuel, building materials, and water for humans and livestock, for irrigation, and for sanitation. This increase is attributed to a combination of human factors and climatic factors. These factors include but are not limited to population pressure, socioeconomic and policy factors, globalization issues, land use patterns and 
practices and climate-related processes, droughts and projected reduction in freshwater availability due to global warming.

Desertification includes the degradation of land in arid, semi-arid, and dry sub-humid areas. It is caused primarily by human activities and climatic variations. One point that is often times misunderstood is that desertification does not refer to the expansion of existing deserts. It occurs because of dry land ecosystems malfunctioning. The primary reasons for desertification are overgrazing, over-cultivation, increased fire frequency, water impoundment, deforestation, over drafting of groundwater, increased soil salinity, and global climate change. These desertification masses cover over one third of the world's land area. These dry lands are extremely vulnerable to over-exploitation and inappropriate land use. Poverty, political instability, deforestation, overgrazing, and bad irrigation practices can all undermine the land's fertility. Over 250 million people are directly affected by desertification. In addition, some one thousand million (or one billion) people in over one hundred countries are at risk. These people include many of the world's poorest, most marginalized, and politically weak citizens. (Source: The United Nations Convention to Combat Desertification: An Explanatory Leaflet).

Desertification also involves the loss of biological or economic productivity and complexity in croplands, pastures, and woodlands. The most commonly cited forms of unsustainable land use are over cultivation, overgrazing, deforestation, and poor irrigation practices. Seventy percent of the world's dry lands (excluding hyper-arid deserts), or some 3,600 million hectares, are degraded. While drought is often associated with land degradation, it is a natural phenomenon that occurs when rainfall is significantly below normal recorded levels for a long time.

Desertification has huge economic consequences - the World Bank estimates that at the global level, the annual income foregone in the areas affected by desertification amounts to US $\$ 42$ billion each year, while the annual cost of fighting land degradation would cost only US\$ 2.4 billion a year. In all, more than 110 countries have dry lands that are potentially threatened by desertification. Africa, Asia and Latin America are the most threatened by desertification. Although better known for their rain forests, Latin America and the Caribbean are actually about one-quarter desert and dry lands. Poverty and pressure on land resources are causing land degradation in many of these dry areas.

According to the last report from the International Panel on Climate Change, tropical deforestation is responsible for approximately $20 \%$ of world greenhouse gas emissions. Halting this destructive trend is now recognized as the most efficient and economical way to effectively counter global warming, which is its second biggest cause (Report by Nicholas Stern on the economics of climate change - October 2006), but also to preserve the rich and irreplaceable biodiversity contained in these forests.

Every year, 13 million hectares of the world's tropical forests are destroyed, mainly by clearing, owing to the rush to expand cultivatable land, and by uncontrolled logging. Approximately 800 million of earth's inhabitants depend on tropical forests for survival. Sustainable development of these resources in Latin America, South Asia and Africa, is still the exception. In the interest of all, it must become the rule.

The United Nations Conference on Environment and Development, 2007 (UNCED) defined desertification as land degradation in the arid, semi-arid, and sub-humid areas resulting from various factors, including climatic variations and human activities. The central focus of the conference was the question of how to relieve the global environmental system through the introduction to the paradigm of sustainable development. This concept emphasized that economic and social progress will depend critically on the preservation of the natural resource base with effective measures to prevent environmental degradation. These areas are subject to serious physical constraints linked to inadequate water resources, low plant formation productivity, and general vulnerability of biological systems and functions. Whereas on an individual basis animal and plant species are each a model of adjustment and resistance, ecological associates and formations are easily disturbed by the pressures exerted by rapidly growing populations and their livestock. Desertification has become a longstanding and increasingly severe problem in many parts of the world and in developing countries in particular.

The most direct effect of deforestation is soil erosion. An estimated 15,000 acres (61 km2) of topsoil are washed away each year, with erosion also damaging other productive infrastructure such as dams, irrigation systems, roads, and coastal marine ecosystems. Soil erosion also lowers the productivity of the land, worsens droughts, and eventually leads to desertification, all of which increase the pressure on the remaining land and trees.

Indirect costs of land degradation and desertification generally include the effects of damages due to sediments in streams, canals, dams, and reservoirs. These are usually harder to assess, and many of the impacts may not be felt directly by the farmer. Reynolds and Stafford-Smith (2004) suggest that a distinction needs to be made between the local costs and the regional impacts. Gully erosion to the local land manager may not result in any discernible decrease in income, yet to the manager of the hydroelectric dam downstream, the increased sedimentation may 
represent real costs in terms of reductions in power generation. Should it be determined that the gully erosion is having an impact on hydroelectric power generation, it still remains to be determined if the gullies can be economically rehabilitated and who should bear the cost. These issues make desertification mitigation complicated.

According to a United Nations Environment Program (UNEP) estimate, 35 per cent of the earth's land surface (4.5 billion ha) - an area approximately the size of North and South America combined - and the livelihoods of the 850 million people who inhabit that land are under threat from desertification. Currently, each year some 21 million ha are reduced to a state of near or complete uselessness. Projections to the year 2000 indicate that loss on this scale will continue if nations fail to step up remedial action (World Bank, 1992).

\section{Desertification in Haiti}

Although well known for its rain forests, Latin America and the Caribbean are actually about one-quarter desert and dry lands $(20,533,000 \mathrm{~km} 2)$. The hyper-arid deserts of the Pacific coast stretch from southern Ecuador, the entire Peruvian shoreline and northern Chile. Further inland, at altitudes of 3,000-4,500 meters, high and dry plains (Altiplano) of the Andean mountains cover large areas of Peru, Bolivia, Chile, and Argentina. To the east of the Andes, an extensive arid region extends from Chaco's northern reaches in Paraguay to Patagonia in southern Argentina. Northeastern Brazil contains semi-arid zones dominated by tropical savannahs. Large parts of Colombia and Venezuela are highly degraded. In Dominican Republic, Cuba, Haiti and Jamaica, there are arid zones, as erosion and water shortages are noticeably intensifying in the Eastern Caribbean. Most of Mexico is arid and semi-arid, mainly in the north. Land degradation and severe droughts make the Central American countries vulnerable to extreme events, delaying their sustainable development. Poverty and pressure on land resources are causing land degradation in many of these areas. This is a region with 465 million inhabitants; around 110 million live below the poverty line.

To the west of the island of Hispaniola is Haiti, only 3\% of which now has forest coverage. Although the Dominican Republic that makes up the east of the island still has $23 \%$. At least $90 \%$ of Haiti's soils have been severely degraded by deforestation and inappropriate cultivation as compared to $40 \%$ for the Dominican Republic. The consequences of deforestation are becoming more drastic each year. Historically, deforestation has been the most rapid in the Caribbean. Figure 1 shows the decrease in forest cover in Haiti from 1990 thru 2005. The total change in land cover between 1990 and 2005 was $-9.48 \%$.

The International Crisis Group has just issues its latest briefing, "Haiti: Saving the Environment, Preventing Instability and Conflict", which argues that "the combination of environmental destruction and other factors such as weak institutions, extreme poverty and rapid population growth raise the risk of serious new trouble in the island republic." The report confirms the centrality of Haiti's environmental crisis to the nation's instability. "The catastrophic state of the environment is closely related to deep-seated institutional, political and governance problems", says Bernice Robertson, Crisis Group's Haiti Analyst. "Coherent national socio-economic development policies have been mostly absent, due to management and political limitations and the narrow interests of those holding economic power". (International Crisis Group, 2009)

Severe environmental problems have been among the roots of Haiti's social, economic and even political crises. Haiti is catastrophically deforested, topsoil has been eroded, and there are zones of galloping desertification. The level of environmental degradation has made Haiti one of the world's most natural disaster-prone countries. Following the devastating floods of 2004, which killed approximately 3,000, Crisis Group warned about future ecological disasters. In 2008, a succession of hurricanes and tropical storms killed close to 800 and left some 100,000 homeless.

Deforestation in Haiti is a severe environmental problem. In 1923, over $60 \%$ of Haiti's land was forested. Deforestation accelerated after Hurricane Hazel downed trees throughout the island in 1954. Beginning in about 1954, concessionaires stepped up their logging operations, in response to Port-au-Prince's intensified demand for charcoal, thus accelerating deforestation, which had already become a problem because of environmentally unsound agricultural practices, rapid population growth, and increased competition over scarce land. Rather than using techniques which could make forestry more productive for fuel, like coppicing and pollarding, the lack of title on much land resulted in charcoal burners digging up and using tree root structures. There is also a less discussed problem with feral goats which overgraze and eat seedlings that might otherwise replace ground cover.

\section{Internal Programs designed to reverse the negative effects of Desertification in Haiti}

The Haitian's government's efforts to combat desertification pre-dates the UNCCD (United Nations Convention to Combat Desertification) as evidenced by a range of policy initiatives facilitating action programs across the spectrum of areas involved in environmental issues. These are a few of the relevant measures. 
4.1 Decree for Environmental Management which provided a framework and structural arrangement for sustainable and land management including a fund for the rehabilitation of the environment. Additionally this decree proposed measures to end the environmental free riders who have historically abused Haiti's natural resources.

4.2 The Inter Institution Steering Committee was designed to be a platform to coordinate sustainable land management interventions for implementation and support of a National Action Plan.

4.3 The National Observatory for Environmental and Vulnerability was created to address information dissemination on the monitoring of land patterns and the identification of sustainable land management systems.

4.4 The development of an agreement between the German Agency for Technical Cooperation (GTZ) and the Canadian International Development Agency (CIDA). This agreement was designed to lead the way for joint activities related to raising awareness, and for strengthening the role of civil participation in co-financing strategies for desertification. (Reconstruction and Disaster Risk Management, n.d.)

4.5 Mixed Commission Republic of Haiti and Dominican Republic Agreement was revived in order to develop a governance mechanism for the management of shared resources originally developed in 1996.

\section{External Programs designed to reverse the negative effects of Desertification in Haiti}

In the past years various governments have expressed growing concerns over the incident of land degradation and the subsequent serious damage to the country's agriculture. There have been a number of initiatives underway that aim to contribute to a better understanding of desertification and to explore policy responses.

5.1 The Dry land Degradation Assessment, a proposed project under the UNEP Global Environmental Facility (GEF), was intended to assist in the development of drylands through the provision of better information on land degradation.

5.2 The Assessment, Research and Integration on Desertification (ARID) is a joint LUCC (Land Use Coverage Change) and Global Change and Terrestrial Ecosystems (GCTE) initiative, the goal of which is to test and refine the Dahlem Desertification paradigm.

5.3 AIRDnet, an international network of researchers with a multitude of case studies, the goal of which is to classify what matters in terms of fast and slow variables, drivers, etc., in which locations, and why, and to develop integrated assessment models. The following programs are examples of those designed specifically to address the desertification needs for Haiti.

5.4 USAID's Agroforestry Outreach Program, Projè Pyebwa - USAID's Agroforestry Outreach Program, Projè Pyebwa (Creole for tree project), was the country's major reforestation program in the 1980s. Pwoje Pyebwa was an on-going Agroforestry Outreach Project (AOP) in Haiti, implemented by the Pan American Development Foundation (PADF) and funded by USAID. The project began in 1981 and incorporated the participation of locals in technical training, and the production and distribution of tree seedlings. As extension strategies have been refined over the course of the project, tree survival and the number of participating farmers has increased. Peasants planted more than 25 million trees under Projè Pyebwa, but as many as seven trees were cut for each new tree planted. Later efforts to save Haiti's trees focused on intensifying reforestation programs, reducing waste in charcoal production, introducing more wood-efficient stoves, and importing wood under USAID's Food for Peace program. Because most Haitians still depend on wood and charcoal as their primary fuel source, energy alternatives are needed to save the forests. The 15-year Environment Action Plan, authorized in 1999, proposed to stop deforestation by developing alternative fuel sources. Political instability and lack of funding have limited the impact of this reform effort. However, various grassroots projects have begun planting thousands of trees in an effort to combat deforestation and to reforest the country, the poverty and fuel issues.

In Haiti erosion is severe. Most farmland is on slopes of over $20 \%$, and $90 \%$ of the farms are less than 3 ha. Studies in the late 1970s showed conventional soil conservation practices were failing in Haiti. When soil conservation did work, usually there was a short-term economic interest on the part of the farmer involved. Primary motivating factors for farmer participation in Pwoje Pyebwa were income and savings, and erosion control and household use.

The project had two main objectives: to motivate Haitians to plant and maintain trees, and to achieve the planting and maintenance of a substantial number of trees for soil conservation, fuel wood and income generation in rural areas. Additionally, the project encouraged farmers to plant trees along the borders of their land, and to alley crop trees with traditional crops. Farmers are encouraged to perpetuate tree cropping by harvesting their own trees, not natural stands. 
The project operated in all five regions of Haiti. PADF functioned through participation in the four regions, and through CARE in the northwest. PADF provided support in several forms, such as: training, and development of training materials, procurement of nursery supplies, provision of technical support and credit for nursery projects, technical assistance and applied research on agroforestry systems, and assistance in the institutional development of participating locals.

PADF established an agroforestry resource center in Port-au-Prince in 1982. Seedling distribution began in three regions that spring, and later expanded to all five regions. Hedgerow intercropping with nitrogen-fixing trees was introduced as a low-cost soil conservation technology in 1984, and expanded rapidly in 1987-88.

During the initial four-year phase of the project 40 regional nurseries were established, and 115 extension contracts with locals were initiated. Regional teams began data collection of species performance. Training materials were developed and published. A system was implemented to monitor seedling survival during the first year. The first phase of the project exceeded expectations and was extended twice. The second extension was based on a Cooperative Agreement (CA).

Project objectives were revised under the $\mathrm{CA}$ and focused on two themes: the significant enhancement of tree survival and growth rates, and consolidation of the program with growth focused on the quality of support services rather than the increase of planting. The CA set production and extension goals for the project. The goals were: to produce 15 million seedlings from 35 nurseries; to incorporate 120,000 participants; to have 9,000 farmers adopt alley cropping; to increase extension personnel to about 600 animators and 60 coordinators; to produce a comprehensive training and nursery package for use by other agroforestry programs. Under the CA, PVO participation increased to 54. Additionally, the CA called for a training officer for each region and a training coordinator, to include women and the poor to a greater extent, and to increase emphasis on follow-up.

Under the CA, three changes were made to the program. They were required to have educational meetings with farmers before enrolling them in the program, an intermediate farm visit was added, and a demonstration site and demonstration garden were to be established and maintained.. In four of the regions, locals were paid per task and per farmer. In another region, they were paid per seedling distribution, and per tree survival after 6 and 9 months with a bonus for high survival rates.

Because hedgerow technology is complex and potential problems are many, it was found to require separate training. However, farmers have been adapting this technology without supervision, a trend that is expected to continue. Project focus shifted from tree planting to tree survival. A new emphasis was placed on upgrading skills, including communication through publications and schools. A training guide was produced in 1986 with an accompanying tree planter's manual. A series of training filmstrips were developed. In 1989 more than 100 training seminars were held. Coordinator involvement increased, and greater attention was paid to their training. Team members upgraded their skills by visiting other project sites and senior staff participated in technical retreats and seminars. Four regions introduced an environmental education component to their school curricula. (Conway 1987, Bannister, 1990)

Despite the advances made, there is still much room for improvement in the follow-up project. There is a need for greater emphasis on training farmers to manage trees and to establish hedgerows, without overloading the locals, who will ultimately be responsible for the success of the project to date. Further improvements are expected in the training program at all levels.

Reconstruction and Disaster Risk Management in the Border Region Haiti/Dominican Republic (Multi-Country Project) - In May 2004, a disastrous flash flood in the border region between Haiti and the Dominican Republic took the lives of several thousand people and destroyed buildings, streets, bridges, livestock and farmland. Heavy rain in the zone threatened by tropical cyclones often brings sudden flooding in dry riverbeds, endangering many villages. The causes of this are largely deforested mountain ranges, farming methods unsuited to the location, extensive grazing and frequent burning to clear farmland.

The objective of this project was to improve the livelihoods of the population in nine municipalities in the southern border region between Haiti and the Dominican Republic and to ensure that these countries are less vulnerable to the effects of natural disasters.

The approach of the project worked on the interface between emergency aid and long-term technical cooperation. It offered the population cooperation in deciding, planning and implementing activities including: the reconstruction/rehabilitation of agricultural and forestry production and marketing infrastructure, and reducing the vulnerability of villages (defenselessness against natural disasters) through soil conservation measures 
(ravine-filling, reforestation) and construction of protective barriers against flash floods for emergency planning and capacity building to cope better with natural disasters.

The project supported local actors through back-up consulting and funding. Due to the short project term and the magnitude of the task, the project made a special effort to cooperate with other actors, governmental institutions, and international and local non-governmental organizations and grassroots organizations.

The results achieved so far with special emphasis on Haiti are the following: completed construction of a water pipeline (7.7 kilometers) in the municipality of Belle, anse and reforestation of headwater region (50 ha), 60 kilometers of ravines filled and reforested, rehabilitation of 12 critical points in the road grid, rehabilitation of the market infrastructure in the municipality of Thiotte, completed rehabilitation/expansion of eight coffee processing centers owned by cooperative, completed establishment of a rotating fund for production means for coffee farmers, participatory preparation of emergency plans, and the expansion of tree nursery and training of personnel.

5.5 Combating Desertification in Central America and Central America - 'Combating Desertification in Central America and the Caribbean' is the name of the German development project that supports the three nations in developing strategies to combat declining soil fertility and the loss of useable areas. National Action Programs, Knowledge Management, Capacity Building and South-South Cooperation form the framework for cooperation. Coordination committees were initially established in all three countries in which the national strategies for sustainable land management are formulated. These committees are made up of representatives from various ministries, civil society and donors.

One goal of the project is to boost awareness of the problems of desertification. A great deal of perseverance will be needed at national level until ministries, civil society and donors can decide on a mutual and coordinated commitment, without which nothing can be achieved. At local level, the causes and effects of desertification are all too familiar. Indeed, solution approaches often exist, but these require joint action. This is why the project promotes cooperation between local organizations, such as in the border region between the Dominican Republic and Haiti, where the income differential between the two countries gives rise to migratory movements and smuggling and also frequent tension. Due to the lack of alternatives and state regulatory mechanisms, unregulated resource exploitation, slash-and-burn practices and the felling of trees take place on both sides of the border. In no other region is the erosion as alarming as here. Cooperation in the field of environmental conservation is a crucial factor in preventing conflict.

5.6 The Sub-Regional Action Programs of Hispaniola (Dominican Republic and Haiti) and Colombia and Venezuela (SRAPS), have shown progress, one in the trans-boundary area and both in institutional cooperation; strengthening of these actions is underway. Concerning the Caribbean, protection of biodiversity, actions and assessment of land degradation, partnership building, and awareness of sustainability of such ecosystems are centre stage. The Mesoamerican countries are jointly aiming to further cooperation efforts on land degradation and drought.

\section{Indicators of desertification for Haiti and the Island of Hispaniola}

The development of desert-like conditions where none existed previously is described as desertification. The definitions of desertification are diverse and include the loss of vegetative cover and plant diversity which are attributable in some part to human activity as well as the element of irreversibility. These definitions are not confined to advancing frontiers of sand that engulf pastures and agricultural land, as often shown visually in the media. Various indicators of this phenomenon are listed in the Table 1. (Barrow, 1991)

This research compares the following indicators of desertification to establish differences that exist on the island of Hispaniola. More specifically, this research compares the desertification indicators for Haiti and Dominican Republic which both share the island of Hispaniola.

Variables used on the research:

1. Percent of forest cover

2. Percentage change in forest cover 1990-2000

3. Percentage change in forest cover 2000-2005

4. Percentage change in forest cover 1990-2005

5. Percentage change in total degradation/ conversion (forest area + wooded area + plantations) 1990 $-2000$ 
6. Percentage change in total degradation/ conversion 2000 - 2005

7. Percentage change in total degradation/ conversion 1990-2005

8. Biodiversity - Plants : Critically Endangered

9. Biodiversity - Plants: Vulnerable

10. Biodiversity - Plants: Vascular Endemic

11. Biodiversity - Plants: Vascular Threatened

Refer to Tables 2 and 3of the appendix for the comparison of desertification variables for the island of Hispaniola.

Approximately $3.8 \%$ or about 105,000 hectares of Haiti is forested. The change in forest cover between 1990 and 2000 was an average of 700 hectares of forest per year. The amounts to an average annual deforestation rate of $0.60 \%$. Between 2000 and 2005 , the rate of forest change increased by $21.6 \%$ to $0.73 \%$ per annum. In total, between 1990 and 2005, Haiti lost 9.5\% of its forest cover, or around 11,000 hectares. Measuring the total rate of habitat conversion in Haiti (defined as change in forest area plus change in woodland area minus net plantation expansion) for $1990-2005$ is approximately $22.1 \%$ of its forest and woodland habitat.

Haiti has some 474 known species of amphibians, birds, mammals and reptiles according to figures from the World Conservation Monitoring Centre. Of these, $16.2 \%$ are endemic, meaning they exist in no other country, and $15.6 \%$ are threatened. Haiti is home to at least 5242 species of vascular plants, of which $31.0 \%$ are endemic.

Approximately $28.4 \%$ - or about 1,376,000 hectares of Dominican Republic is forested. The Change in forest cover: between 1990 and 2000 had no significant change or no reported in forest cover.

Dominican Rep has some 415 known species of amphibians, birds, mammals and reptiles according to figures from the World Conservation Monitoring Centre. Of these, $14.5 \%$ are endemic, meaning they exist in no other country, and $14.9 \%$ are threatened. Dominican Rep is home to at least 5657 species of vascular plants, of which $31.8 \%$ are endemic. $22.9 \%$.

\section{Consequences of Desertification for Haiti}

For years, severe environmental problems have been among the roots of Haiti's social, economic and even political crises. Desertification has huge economic consequences - the World Bank estimates that at the global level, the annual income foregone in the areas affected by desertification amounts to US\$ 42 billion each year, while the annual cost of fighting land degradation would cost only US\$ 2.4 billion a year. In all, more than 110 countries have drylands that are potentially threatened by desertification. Africa, Asia and Latin America are the most threatened by desertification. Although better known for their rain forests, Latin America and the Caribbean are actually about one-quarter desert and drylands. Poverty and pressure on land resources are causing land degradation in many of these dry areas.

So, the question becomes, "What can be done to reverse the negative consequences of desertification?"

- Restore and fertilize the land - This could be done by preparing compost that will become humus and will regenerate the soil with organic matter. Combat the effects of the wind by constructing barriers and stabilizing sand dunes with local plant species.

- Reforestation - Trees play several roles: they help fix the soil, act as wind breakers, enhance soil fertility, and help absorb water during heavy rainfall. Because the burning of land and forests increases dangerous greenhouse gases, planting new trees - can help reduce the negative impacts of resulting climate change.

- Develop sustainable agricultural practices - Drylands are home to a large variety of species that can also become important commercial products: for example, they provide $1 / 3$ of the plant-derived drugs in the United States. Agriculture biodiversity must be preserved. Land overexploitation shall be stopped by leaving the soil 'breathe' during a certain-time period, with no cultivation, nor livestock grazing.

- Developing traditional lifestyles changes - Traditional lifestyles as practiced in many arid zones offer examples of harmonious living with the environment. In the past, nomadism was particularly adapted to drylands conditions; moving from one waterhole to another, never staying on the same land; pastoral peoples didn't exert much pressure on the environment. However, changing lifestyles and population growth are putting increasing pressure on scarce resources and vulnerable environments.

- Mandating environmental priority changes - Make the environment a national priority and link environmental rehabilitation and preservation measures to social and economic development strategies, such as the Poverty Reduction Strategies. 
- Relieving pressure on forest resources - Encourage the use of subsidized wood fuel substitutes, taxing the sale and transport of charcoal and wood and investing returns in environmental rehabilitation programs.

- Investing more external aid in rural development - The main goal should be to stem the flow of migrants to urban slums and stepping up community-led environmental protection projects in those slums to expand access to clean water and basic sanitation.

- Strengthening institutions- The goal is for better manage the environment by establishing and empowering local governance structures.

\section{References}

Ahmad, Y.J. and M. Kassas. (1987). Desertification: Financial Support for the Biosphere. West Hartford, Conn.: Kumarian Press.

Bannister, M., P. -Nair. (1990). Alley Cropping as a sustainable agricultural technology for the hillsides in Haiti: Experience of an Agroforestry outreach project, American Journal of Alternative Agriculture, vol. 5(2).

Barrow, C. J. (1991). Land Degradation - Developments and Breakdown of Terrestrial Environments. Cambridge: Cambridge University Press.

Conway, Dr. J. Jickling, J. Haiti Agroforestry Outreach Project Extension, (1987-90). Pan American Development Foundation.

Desertification Tables and Charts for Haiti. Retrieved from http://rainforest.mongabay.com/deforestation/Haiti.html

Executive Summary Third National Report of the Republic of Haiti (2006), Retrieved from http://www.unccd.int/cop/reports/lac/national/2006/haiti-summary-eng.pdf

International Crisis Group. (2009). Haiti: Saving the Environment, Preventing, Instability and Conflict, Retrieved from http:/www.crisisgroup.org/home/index.cfm?id=6078\&l=1

Reining, P. (1978). Handbook on Desertification Indicators. Washington, D.C.: American Association for the Advancement of Science.

Reconstruction and Disaster Risk Management. $\quad$ Retrieved from http://gtz.de/en/weltweit/lateinamerika-karibik/haiti/19056.htm

J.F. Reynolds and D.M. Stafford Smith. (2004). "Global Desertification's, Do Humans cause Deserts?", Environmental Science and Policy, Volume 7, Issue 2, April 2004, pp.118-199.

UNEP (United Nations Environment Programme). (1984). General Assessment of Progress in the Implementation of the Plan of Action to Combat Desertification, 1978-1984. GC-12/9.

World Bank. (1992). World Development Report. (1992). Oxford: Oxford University Press. 


\begin{tabular}{|c|c|}
\hline $\begin{array}{l}\text { Table } 1 . \quad \text { Indicators of } \\
\text { Desertification }\end{array}$ & Decrease in soil depth \\
\hline Physical indicators & Decrease in soil organic matter \\
\hline & Decrease in soil fertility \\
\hline & Soil crust formation/compaction \\
\hline & $\begin{array}{l}\text { Appearance/increase in frequency/severity of dust sandstorms/dune } \\
\text { formation and movement }\end{array}$ \\
\hline & Stalinization/alkalinization \\
\hline & Decline in quality and quantity of ground and surface water \\
\hline & Increased seasonality of springs and small streams \\
\hline & Alteration in relative reflectance of land (albedo change) \\
\hline Biological indicators & \\
\hline Vegetation & Decrease in cover \\
\hline & Decrease in above-ground biomass \\
\hline & Decrease in yield \\
\hline & Alteration of key species distribution and frequency \\
\hline & Failure of species successfully to reproduce \\
\hline Animal & Alteration in key species distribution and frequency \\
\hline & Change in population of domestic animals \\
\hline & Change in herd composition \\
\hline & Decline in livestock production \\
\hline & Decline in livestock yield \\
\hline Social/economic indicators & Change in land use/water use \\
\hline & Change in settlement pattern (e.g. abandonment of villages) \\
\hline & $\begin{array}{l}\text { Change in population (biological) parameters (demographic evidence, } \\
\text { migration statistics, public health information) }\end{array}$ \\
\hline & $\begin{array}{l}\text { Change in social process indicators - increased conflict between } \\
\text { groups/tribes, marginalization, migration, decrease in incomes and assets, } \\
\text { change in relative dependence on cash crops/subsistence crops }\end{array}$ \\
\hline
\end{tabular}


Figne 1 hatianTotal Forest Coner 19002005

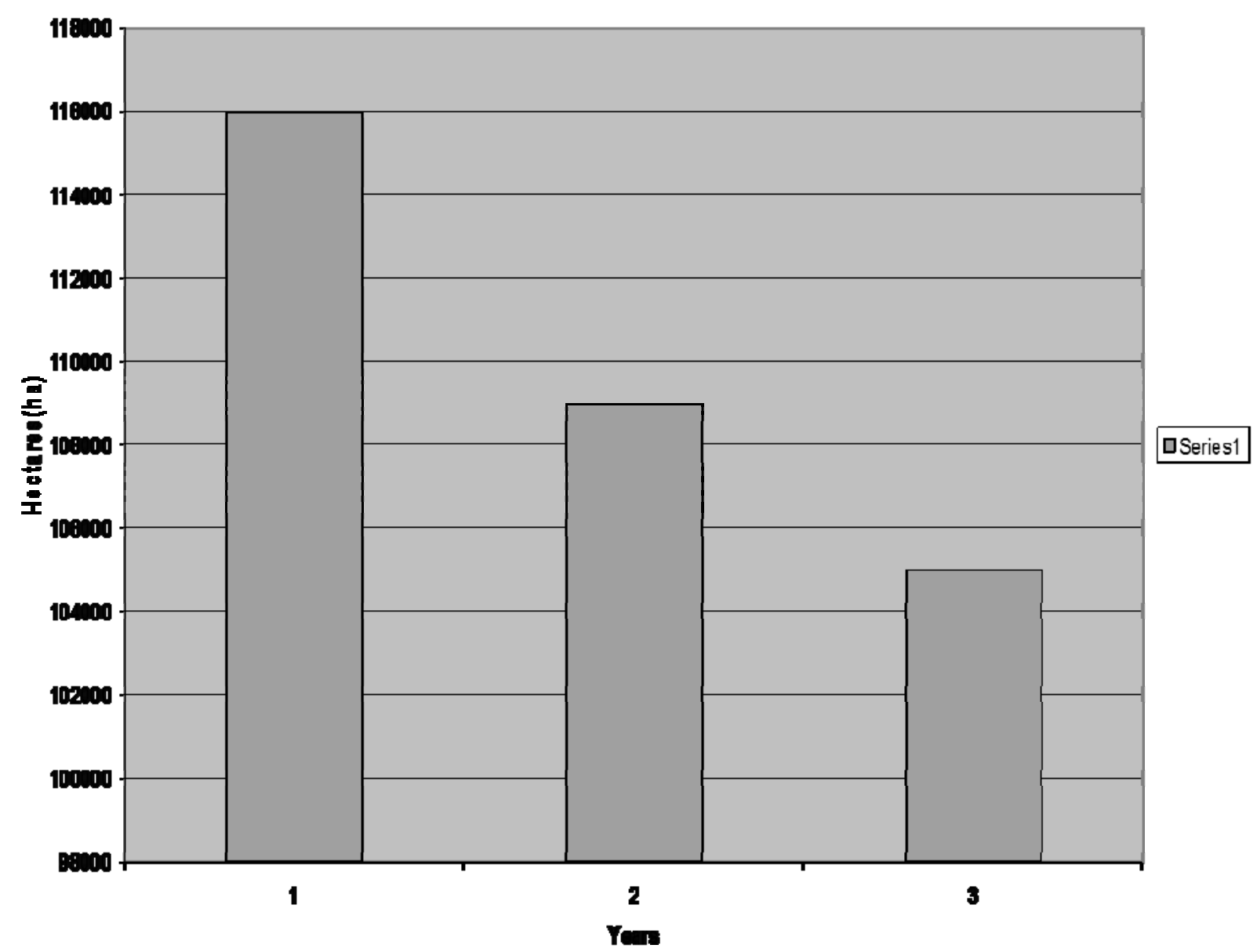

Figure 1. Haitian Total Forest Cover 1990-2005

Data Source: http://rainforest.mongabay.com/deforestation/Haiti.html 


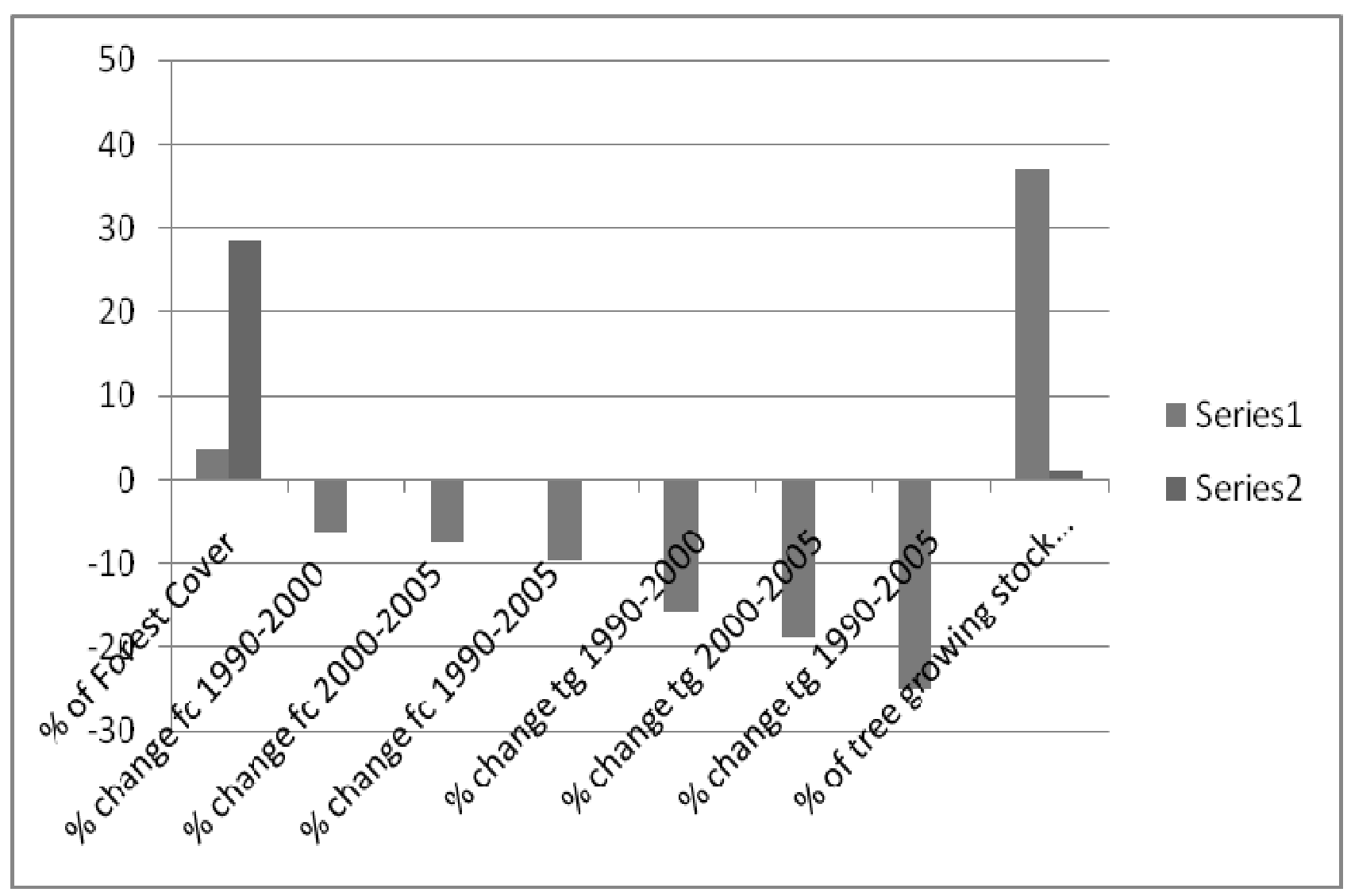

Figure 2. A Comparison of Selected Desertification Variables for Haiti and Dominican Republic (Series 1 is Haiti and Series 2 is Dominican Republic) Source: http://rainforests.mongabay.com/deforestation/2000/Dominican_Republic.htm 


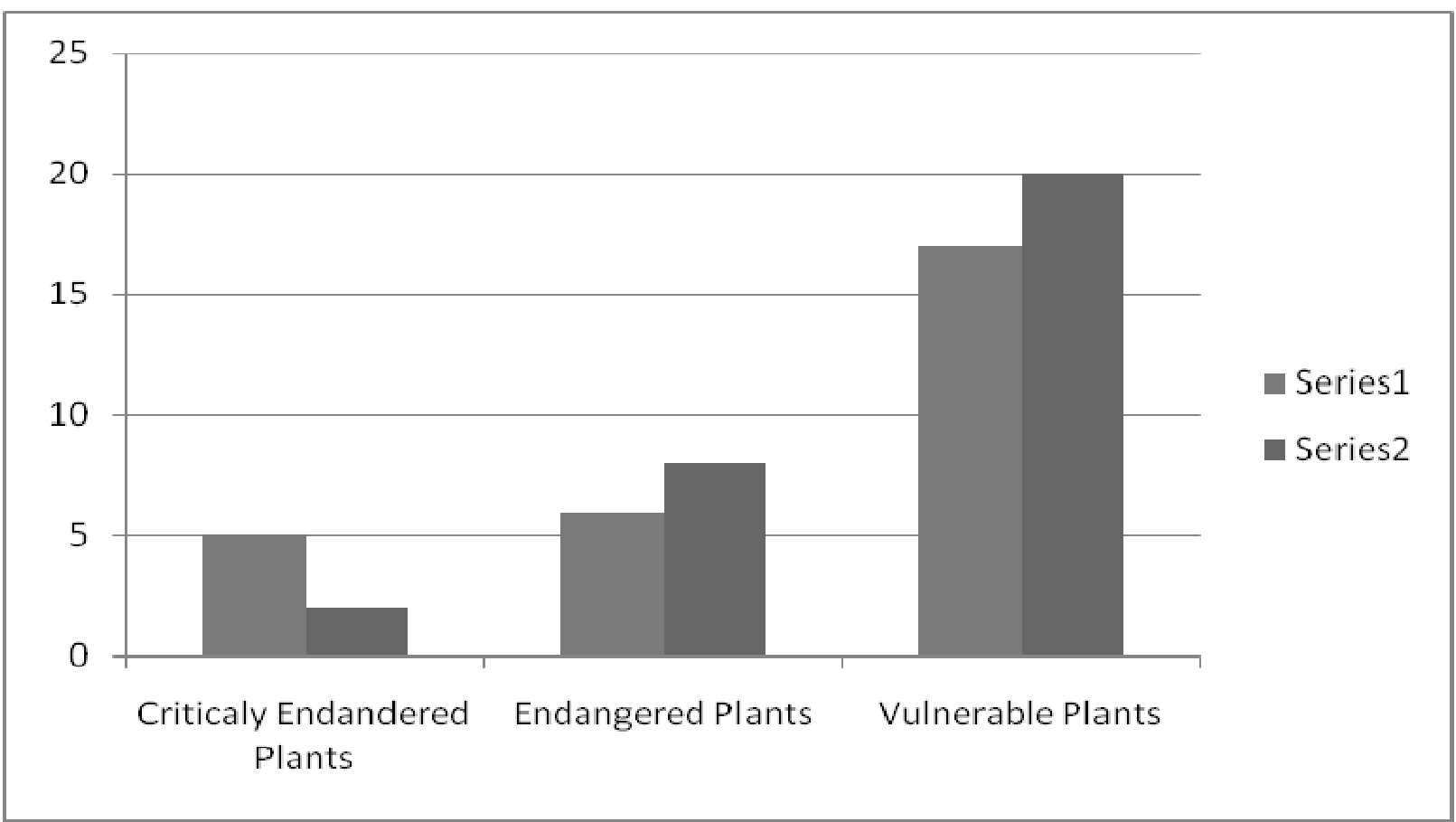

Figure 3. Endangered Plants Variable Comparisons for Haiti and Dominican Republic (Series 1 is Haiti and Series 2 is Dominican Republic)

Source: http://rainforests.mongabay.com/deforestation/2000/Dominican_Republic.htm 